\title{
INTEGRAÇÃO DE DADOS GRAVIMÉTRICOS TERRESTRES E AEROMAGNÉTICOS E SUA APLICAÇÃO AO ESTUDO GEOLÓGICO ESTRUTURAL DA FAIXA APIAÍ
}

\author{
Mario Jesus Tomas Rosales \\ Orientador: Dr. Wladimir Shukowsky (IAG-USP) \\ 271 p. - Tese (Doutorado) - Defesa 15.04 .2005
}

\begin{abstract}
RESUMO. A Faixa Apiaí, compreendendo a porção sudeste do cinturão Ribeira, é constituída por complexas associações metassedimentares subordinadamente metavulcânicas de idade Proterozóico Médio-Inferior, afetadas por intrusões diversas, fundamentalmente constituídas por rochas de composição intermediária-ácida do Proterozóico Superior e por rochas Mesozóicas de composição básica-ultrabásica, assim como pela presença de um extenso feixe de diques de gabros e diabásios, orientado segundo a direção SE-NW, com ocorrência de afloramentos próximo a cidade de Guapiara, sendo o conjunto todo secionado por grandes falhas transcorrentes destrais, com direções próximas a NE-SW. 0 presente trabalho visou a utilização de dados gravimétricos terrestres e aeromagnéticos, cobrindo uma área de aproximadamente $31600 \mathrm{~km}^{2}$, com o objetivo principal de complementar o mapeamento geológico existente na Faixa Apiaí, bem como contribuir para o conhecimento acerca da evolução geológica e das características da crosta continental na Faixa Apiaí, referentes à estrutura, espessura e provável composição petrográfica. Os dados gravimétricos terrestres e aeromagnéticos foram interpretados qualitativamente, utilizando técnicas de filtragem e de transformação do potencial, e quantitativamente, por modelamento 2,5 D ao longo de perfis, tendo-se como principais resultados: Modelos geofísicos estruturais caracterizaram segundo NE-SW as falhas de Itapirapuã, Conceição do Herval, Quarenta Oitava, Figueira, Faxinal e Alexandra, como falhas profundas que afetam tectonicamente as rochas do embasamento. Importantes falhas profundas na direção N-S foram reveladas pela interpretação geofísica na porção central da região de estudo (Ex. falha Morro Agudo). Na região central da Faixa Apiaí, limitada pela falha Conceição do Herval e pela falha Figueira, foi revelada a presença de uma estrutura deprimida denominada bacia de Lajeado, que apresenta um formato de bloco, afetada tectonicamente em sua parte central pela falha Quarenta Oitava, preenchida dominantemente por pacotes de rochas metassedimentares que atingem espessuras em torno de $2 \mathrm{~km}$. Uma nova estrutura geológica de caráter profundo que apresenta formato circular foi revelada nas imediações de Araçaíba, interpretada como um corpo intrusivo de composição básica, denominado "gabro Araçaíba - Apiaí". Na área a Sul-Sudeste de Guapiara, fortes evidências gravimétricas identificaram uma feição anômala com características próprias muito bem definidas, interpretada como um "setor soerguido" da base da crosta superior, a uma profundidade aproximada de $12 \mathrm{~km}-14 \mathrm{~km}$ com seu eixo orientado segundo N40 W, que foi denominada "Arco estrutural de Guapiara". A interpretação gravimétrica caracterizou as rochas do Complexo granítico Três Córregos (Tc) constituindo um domínio litoestrutural bem definido, delimitado pela presença da falha Conceição do Herval a leste e a falha Itapirapuã a oeste. 0 valor médio da espessura da crosta continental para a região da Faixa de Apiá foi estimado em 37 km. Fortes evidências gravimétricas indicam um gradual afinamento da crosta superior na direção SE, mostrando-se mais significativo ao sul da falha Faxinal em direção ao litoral.
\end{abstract}

ABSTRACT. The Apiaí Belt, encompassing the southeastern portion of the Ribeira Belt, is composed of complex associations of metasediments, subordinately metavocanics, of Medium to Lower Proterozoic age, intruded by Upper Proterozoic granitoids, by Mesozoic basic and ultrabasic rocks, as well as by gabro and diabase dyke swarms oriented SE-NW, with the whole assembly being cut by big transcurrent dextral faults, with directions close to NE-SW. Terrestrial gravity and aeromagnetic data covering an area of approximately $31600 \mathrm{~km}^{2}$, were utilized with the main objective of refining the existing geological mapping of the Apiai Belt, as well as contribute for the knowledge about the geological evolution and the characteristics of the continental crust in the Apiaí Belt, regarding it's structure, thickness and probable petrographic composition. The terrestrial gravity and aeromagnetic data were interpreted qualitatively, utilizing filtering and potential transform techniques, and quantitatively, by $2.5 \mathrm{D}$ modeling along profiles. The main results are as follows: The interpretive models identified the NE-SW oriented faults of Itapirapuã, Conceição do Herval, Quarenta Oitava, Figueira, Faxinal and Alexandra, as deep seated faults that affect tectonically the basement rocks. Several N-S oriented faults were inferred by the geophysical interpretation, all of them extending into the interior of the Basin of the Paraná. A new geological structure was inferred in central part of the Apiaí Belt, in the immediacies of Araçaíba. It was interpreted as an intrusive body of basic composition, named here as "Araçaíba - Apiai gabro". In the area to the southeast of Guapiara, a well defined anomaly was interpreted as an uplifted sector of the upper crust at a depth around $12 \mathrm{~km}$ with it's axis oriented along N40 $\mathrm{W}$, and was named "structural Arch of Guapiara". In the central region of the Apiaí Belt, limited by the Conceição do Herval and Figueira faults, it was inferred the presence at depth of a depressed structure with a format of a nearly vertical block, tectonically affected by the Quarenta Oitava fault, filled by thick packages of metasedimentary and volcano-sedimentary rocks, with intercalation of metabasites of the Lajeado subgroup. This feature was interpreted as a forearc basin. The average thickness of the continental crust for the Apiaí Belt region was estimated at $37 \mathrm{~km}$. A strong regional gravity gradient in the SE direction was interpreted as a significant crustal thinning towards to the coastline. 